\title{
Pengaruh Aplikasi PGPR dan Jenis Pestisida terhadap Pertumbuhan dan Hasil Tanaman Selada (Lactuca sativa, L.)
}

Yunitha Maria Naikofi a ${ }^{\text {, dan Aloysius Rusae }}{ }^{\mathrm{b}}$

${ }^{a}$ Fakultas Pertanian, Universitas Timor, Kefamenanu, TTU - NTT, Indonesia.

${ }^{b}$ Fakultas Pertanian, Universitas Timor, Kefamenanu, TTU - NTT, Indonesia.

\section{Article Info}

Article history:

Received 18 Juli 2017

Received in revised form 1 September 2017

Accepted 9 September 2017

Keywords:

Plant Growth Promoting Rhizobacteria

Pestisida Hayati

Pestisida Organik Daun Sirih

Selada

\section{Abstrak}

Tujuan penelitian ini adalah untuk mengetahui frekuensi aplikasi PGPR dan jenis pestisida yang tepat terhadap pertumbuhan dan hasi tanaman selada (Lactuca sativa, L.). Rancangan percobaan yang digunakan adalah Rancangan Acak Kelompok faktorial $3 \times 3$ dengan 3 kali ulangan. Faktor pertama adalah aplikasi PGPR yang terdiri dari 3 aras yaitu, tanpa PGPR, penyiraman 1 minggu sekali, penyiraman 2 minggu sekali. Faktor kedua jenis pestisida dengan 3 aras yakni tanpa pestisida, pestisida ekstrak daun sirih dan pestisida hayati. Penelitian dilaksanakan dari bulan Februari sampai Maret 2017 di kebun percobaan Fakultas Pertanian, Universitas Timor. Hasil penelitian menunjukkan bahwa tidak ada pengaruh interaksi antara aplikasi PGPR dan jenis pestisida terhadap pertumbuhan dan hasil selada. Aplikasi PGPR hanya berpengaruh nyata terhadap berat kering akar sedangkan jenis pestisida hanya berpengaruh terhadap berat kering trubus. Aplikasi PGPR dengan frekuensi dua minggu sekali menghasilkan selada setiap petak paling berat ( $253,71 \mathrm{~g})$, sedangkan jenis pestisida yang menghasilkan selada setiap petak paling berat adalah pestisida hayati (198,38 g). @2017 dipublikasikan oleh Savana Cendana.

\section{Pendahuluan}

Selada (Lactuca sativa, L.) merupakan sayuran daun yang berasal dari daerah (Negara) beriklim sedang. Menurut sejarahnya, tanaman selada telah dibudidayakan sejak 2500 tahun yang lalu. Tanaman selada berasal dari kawasan Amerika. Hal ini dibuktikan oleh Christoper Columbus pada tahun 1493 yang menemukan tanaman selada di daerah Hemisphere bagian barat dan Bahamas (Rukmana, 1994). Selada dapat disukai oleh masyarakat karena Jenis sayur in mengandung zat-zat gizi seperti protein, vitamin B, vitamin C untuk memenuhi kebutuhan gizi masyarakat. Selada sebagai bahan makanan yang dapa dikonsumsi dalam bentuk segar sebagai lalapan dan dimakan bersama dengan bahan makanan lain (Wicaksono, 2008).

PGPR merupakan konsorsium bakteri yang aktif mengkolonisasi akar tanaman yang berperan penting dalam meningkatkan pertumbuhan tanaman, hasil panen dan kesuburan lahan (Gusti et al., 2012). Prinsip pemberian PGPR adalah meningkatkan jumlah bakteri yang aktif di sekitar perakaran tanaman sehingga memberikan keuntungan bagi tanaman. Keuntungan penggunaan PGPR adalah meningkatkan kadar mineral dan fiksasi nitrogen, meningkatkan toleransi tanaman terhadap cekaman lingkungan, sebagai biofertiliser, agen biologi control, melindungi tanaman dari patogen tumbuhan serta peningkatan produksi indol-3-acetic acid (IAA) (Figueiredo et al., 2010).

Pupuk hayati adalah sebuah komponen yang mengandung mikroorganisme hidup yang diberikan ke dalam tanah sebagai inokulan untuk membantu menyediakan unsur hara tertentu bagi tanaman. Pupuk hayati dapat berisi bakteri yang berguna untuk memacu pertumbuhan tanaman, sehingga hasil produksi tanaman tetap tinggi dan berkelanjutan. Dalam Peraturan Menteri Pertanian (2009), pupuk hayati adalah produk biologi aktif terdiri dari mikroba yang dapat meningkatkan efisiensi pemupukan, kesuburan dan kesehatan tanah. Aplikasi pupuk hayati menjadi pelengkap yang sangat baik, karena selain meningkatkan kesuburan tanah juga memacu pertumbuhan tanaman. Pupuk hayati berperan mempermudah penyediaan hara, dekomposisi bahan organik dan menyediakan lingkungan rhizosfer lebih baik yang pada akhirnya mendukung pertumbuhan dan peningkatan produksi tanaman (Vessey, 2003). Belakangan ini petani mulai memberikan perhatian besar terhadap aplikasi pupuk hayati di Indonesia. Salah satu yang mendorong hal tersebut yaitu kesadaran petani terhadap kemunduran kesuburan tanah dan ketergantungan pupuk anorganik (Simanungkalit, 2001).

2. Metode

Penelitian dilaksanakan pada bulan Februari sampai Maret tahun 2017 di kebun percobaan Fakultas Pertanian, Universitas Timor, Kelurahan Sasi, Kecamatan Kota Kefamenanu, Kabupaten Timor Tengah Utara (TTU). Penelitian disusun menggunakan Rancangan Acak Kelompok (RAK) faktorial 3 x 3 dengan 3 kali ulangan. Frekuensi penyiraman PGPR merupakan faktor pertama yang terdiri dari 3 aras, yaitu tanpa PGPR $\left(\mathrm{t}_{0}\right)$, satu minggu sekali $\left(\mathrm{t}_{1}\right)$ dan dua minggu sekali $\left(\mathrm{t}_{2}\right)$. Faktor kedua adalah jenis pestisida yang terdiri dari tiga aras, yaitu tanpa pestisida $\left(\mathrm{p}_{0}\right)$ pestisida organik daun sirih $\left(\mathrm{p}_{1}\right)$ dan pestisida hayati $\left(\mathrm{p}_{2}\right)$.

Benih yang digunakan adalah benih selada varietas Grand Rapids, yang telah diseleksi dengan cara direndamkan di dalam air untuk memilih benih yang bernas. Tanah terlebih dahulu dibersihkan dari gulma serta vegetasi lainya selanjutnya dilakukan pengolahan. Pengolahan tanah dilakukan dengan menggunakan cangkul, kemudian tanah digemburkan. Lahan yang digunakan berukuran panjang $11,40 \mathrm{~m}$ lebar $4 \mathrm{~m}$ dengan luas lahan $45,6 \mathrm{~m}^{2}$. Lahan dibagi dalam tiga blok, di dalam satu blok terdapat 9 petak percobaan dengan ukuran petak $1 \mathrm{~m}$ x $1 \mathrm{~m}$ sehingga secara keseluruhan terdapat 27 petak percobaan. Jarak antar petak $0,3 \mathrm{~m}$, jarak antar blok $0,5 \mathrm{~m}$.

Tempat Persemaian berupa bale-bale dengan ukurannya tinggi $100 \mathrm{~cm}$, lebar $100 \mathrm{~cm}$, panjang $150 \mathrm{~cm}$. Media semai berupa campuran tanah ayakan dengan pupuk kandang sapi. Sebelum benih selada disemai terlebih dahulu melakukan perendaman PGPR dengan air 5 liter selama 15 menit agar benih selada dapa tumbuh dengan baik dan terhindar dari hama dan penyakit. Benih ditaburkan secara merata kemudian ditutup dengan tanah yang tipis dan disiram air dengan hati-hati. Pada umur 14 hari, bibit dipindahkan langsung ke bedengan yang sudah disiapkan.

Sebelum melakukan penaman terlebih dahulu akar tanaman direndam dalam PGPR selama 5 menit. Penanaman dilakukan serempak pada semua petak pada sore hari dengan cara ditugal sedalam $1 \mathrm{~cm}$, jumlah bibit per lubang adalah satu bibit. Jarak tanam yang digunakan adalah $20 \times 20 \mathrm{~cm}$. Penyiraman dilakukan dua kali sehari yaitu pagi dan sore hari pada tanaman yang masih muda (sampai umur 35 hari) kecuali pada hari dimana aplikasi PGPR dilakukan. Panen dilakukan pada tanaman selada yang telah memiliki daun dengan ukuran maksimal pada umur $35 \mathrm{HST}$.

Data hasil pengamatan kemudian dianalisis dengan menggunakan sidik ragam (Anova) Rancangan Acak Kelompok (RAK). Rata-rata perlakuan selanjutnya diuji lanjut dengan menggunakan Tukey test dengan tingkat signifikan 5\% sesuai petunjuk Gomez dan Gomez (1995). Analisis data menggunakan program SAS 9.1

\section{Hasil dan Pembahasan}

\subsection{Tinggi Tanaman}

Berdasarkan hasil sidik ragam (Anova), perlakuan aplikasi PGPR dan jenis pestisida terhadap tinggi tanaman tidak terjadi interaksi. Namun pemberian pestisida hayati pada pengamatan 35 HST meningkatkan tinggi tanaman dibanding perlakuan pestisida ekstrak daun sirih dan kontrol, demikian juga aplikasi PGPR tidak memberikan pengaruh yang nyata namun pada pengaplikasian 2 minggu sekali memberikan nilai tertinggi di bandingkan dengan perlakuan lainnya.

Tabel 1. Tinggi Tanaman $(\mathrm{cm})$

\begin{tabular}{|c|c|c|c|c|c|}
\hline \multirow[b]{2}{*}{$\begin{array}{c}\text { Waktu } \\
\text { Pengamatan }\end{array}$} & \multirow[b]{2}{*}{ Aplikasi PGPR } & \multicolumn{3}{|c|}{ Jenis Pestisida } & \multirow[b]{2}{*}{ Rerata } \\
\hline & & Kontrol & $\begin{array}{l}\text { Daun } \\
\text { Sirih }\end{array}$ & Hayati & \\
\hline \multirow{4}{*}{$14 \mathrm{HST}$} & Kontrol & $3,11 \mathrm{a}$ & $3,00 \mathrm{a}$ & $3,00 \mathrm{a}$ & $3,04 \mathrm{a}$ \\
\hline & 1 Minggu Sekali & $3,33 \mathrm{a}$ & $3,22 \mathrm{a}$ & $4,11 \mathrm{a}$ & $3,56 \mathrm{a}$ \\
\hline & 2 Minggu Sekali & $2,44 \mathrm{a}$ & $3,22 \mathrm{a}$ & $3,78 \mathrm{a}$ & $3,15 \mathrm{a}$ \\
\hline & Rerata & $2,96 \mathrm{a}$ & $3,15 \mathrm{a}$ & $3,63 \mathrm{a}$ & $(-)$ \\
\hline \multirow{4}{*}{$21 \mathrm{HST}$} & Kontrol & $4,59 \mathrm{a}$ & $4,94 \mathrm{a}$ & $5,06 \mathrm{a}$ & $4,86 \mathrm{a}$ \\
\hline & 1 Minggu Sekali & $5,33 \mathrm{a}$ & $5,11 \mathrm{a}$ & $5,56 \mathrm{a}$ & 5,33 a \\
\hline & 2 Minggu Sekali & $4,39 \mathrm{a}$ & $4,88 \mathrm{a}$ & $5,18 \mathrm{a}$ & $4,81 \mathrm{a}$ \\
\hline & Rerata & $4,77 \mathrm{a}$ & $4,98 \mathrm{a}$ & $5,26 \mathrm{a}$ & $(-)$ \\
\hline \multirow{4}{*}{$28 \mathrm{HST}$} & Kontrol & $5,33 \mathrm{a}$ & $5,33 \mathrm{a}$ & $5,89 \mathrm{a}$ & $5,52 \mathrm{a}$ \\
\hline & 1 Minggu Sekali & $5,28 \mathrm{a}$ & $5,61 \mathrm{a}$ & $5,67 \mathrm{a}$ & $5,52 \mathrm{a}$ \\
\hline & 2 Minggu Sekali & $4,72 \mathrm{a}$ & $5,83 \mathrm{a}$ & $5,56 \mathrm{a}$ & 5,37 a \\
\hline & Rerata & $5,11 \mathrm{a}$ & $5,59 \mathrm{a}$ & $5,70 \mathrm{a}$ & $(-)$ \\
\hline \multirow{4}{*}{$35 \mathrm{HST}$} & Kontrol & $7,50 \mathrm{a}$ & $7,39 \mathrm{a}$ & $8,61 \mathrm{a}$ & 7,83 a \\
\hline & 1 Minggu Sekali & $8,17 \mathrm{a}$ & $7,78 \mathrm{a}$ & $7,86 \mathrm{a}$ & $7,94 \mathrm{a}$ \\
\hline & 2 Minggu Sekali & $6,72 \mathrm{a}$ & $8,83 \mathrm{a}$ & $8,61 \mathrm{a}$ & 8,06 a \\
\hline & Rerata & $7,46 \mathrm{a}$ & $8,00 \mathrm{a}$ & $8,36 \mathrm{a}$ & $(-)$ \\
\hline
\end{tabular}
menurut uji DMRT. (-): Tidak terjadi interaksi antar faktor.

\subsection{Jumlah Daun}

Jumlah daun selalu meningkat sesuai dengan umur tanaman. Hasil sidik ragam (Anova) menunjukkan tidak terjadi interaksi antara perlakuan aplikasi PGPR dan jenis pestisida. Namun pemberian pestisida hayati pada pengamatan 35 HST meningkatkan jumlah daun dibanding perlakuan pestisida ekstrak daun sirih dan kontrol, demikian pula aplikasi PGPR tidak memberikan pengaruh yang nyata namun pada pengaplikasian untuk seminggu sekali memberikan nilai tertinggi dibandingkan dengan perlakuan 2 minggu sekali dan kontol. 
Tabel 2. Jumlah Daun (Helai)

\begin{tabular}{|c|c|c|c|c|c|}
\hline \multirow[b]{2}{*}{$\begin{array}{c}\text { Waktu } \\
\text { Pengamatan }\end{array}$} & \multirow[b]{2}{*}{ Aplikasi PGPR } & \multicolumn{3}{|c|}{ Jenis Pestisida } & \multirow[b]{2}{*}{ Rerata } \\
\hline & & Kontrol & $\begin{array}{l}\text { Daun } \\
\text { Sirih }\end{array}$ & Hayati & \\
\hline \multirow{4}{*}{$14 \mathrm{HST}$} & Kontrol & $2,33 \mathrm{a}$ & $2,78 \mathrm{a}$ & $2,56 \mathrm{a}$ & $2,56 \mathrm{a}$ \\
\hline & 1 Minggu Sekali & $2,89 \mathrm{a}$ & $2,78 \mathrm{a}$ & $2,89 \mathrm{a}$ & $2,85 \mathrm{a}$ \\
\hline & 2 Minggu Sekali & $2,33 \mathrm{a}$ & $2,44 \mathrm{a}$ & $2,78 \mathrm{a}$ & $2,52 \mathrm{a}$ \\
\hline & Rerata & $2,52 \mathrm{a}$ & $2,67 \mathrm{a}$ & $2,74 \mathrm{a}$ & $(-)$ \\
\hline \multirow{4}{*}{$21 \mathrm{HST}$} & Kontrol & $3,11 \mathrm{a}$ & $3,00 \mathrm{ab}$ & $3,00 \mathrm{ab}$ & $3,04 \mathrm{a}$ \\
\hline & 1 Minggu Sekali & $3,33 \mathrm{ab}$ & $3,22 \mathrm{ab}$ & $4,11 \mathrm{a}$ & $3,56 \mathrm{a}$ \\
\hline & 2 Minggu Sekali & $2,44 \mathrm{~b}$ & $3,22 \mathrm{ab}$ & $3,78 \mathrm{ab}$ & $3,15 \mathrm{a}$ \\
\hline & Rerata & $2,96 \mathrm{a}$ & $3,15 \mathrm{a}$ & $3,63 \mathrm{a}$ & $(-)$ \\
\hline \multirow{4}{*}{$28 \mathrm{HST}$} & Kontrol & $4,22 \mathrm{a}$ & $4,11 \mathrm{a}$ & $4,11 \mathrm{a}$ & $4,15 \mathrm{a}$ \\
\hline & 1 Minggu Sekali & $4,11 \mathrm{a}$ & $4,67 \mathrm{a}$ & $4,78 \mathrm{a}$ & $4,52 \mathrm{a}$ \\
\hline & 2 Minggu Sekali & $3,44 \mathrm{a}$ & $4,22 \mathrm{a}$ & $4,56 \mathrm{a}$ & $4,07 \mathrm{a}$ \\
\hline & Rerata & $3,93 \mathrm{a}$ & $4,33 \mathrm{a}$ & $4,48 \mathrm{a}$ & $(-)$ \\
\hline \multirow{4}{*}{$35 \mathrm{HST}$} & Kontrol & $5,11 \mathrm{a}$ & $4,89 \mathrm{a}$ & $5,56 \mathrm{a}$ & 5,19 a \\
\hline & 1 Minggu Sekali & $5,33 \mathrm{a}$ & $5,22 \mathrm{a}$ & $6,00 \mathrm{a}$ & $5,52 \mathrm{a}$ \\
\hline & 2 Minggu Sekali & $4,56 \mathrm{a}$ & $5,22 \mathrm{a}$ & $5,89 \mathrm{a}$ & $5,22 \mathrm{a}$ \\
\hline & Rerata & $5,00 \mathrm{a}$ & $5,11 \mathrm{a}$ & $5,81 \mathrm{a}$ & $(-)$ \\
\hline
\end{tabular}
menurut uji DMRT. (-): Tidak terjadi interaksi antar faktor.

\subsection{Luas Daun}

Hasil analisis sidik ragam (Anova) menunjukkan bahwa perlakuan aplikas PGPR dan jenis pestisida tidak terjadi interaksi terhadap luas daun. Namun pemberian pestisida hayati meningkatkan luas daun dibanding dengan perlakuan pestisida ekstrak daun sirih dan kontrol, demikian juga aplikasi PGPR tidak memberikan pengaruh yang nyata namun aplikasi PGPR 2 minggu sekali memberikan daun terluas dibandingkan dengan perlakuan lain.

Tabel 3. Luas Daun $\left(\mathrm{cm}^{2}\right)$

\begin{tabular}{lcccc}
\hline \multirow{2}{*}{ Aplikasi PGPR } & \multicolumn{3}{c}{ Jenis Pestisida } & \multirow{2}{*}{ Rerata } \\
\cline { 2 - 4 } & Kontrol & Daun Sirih & Hayati & \\
\hline Kontrol & $4.524 \mathrm{a}$ & $3.431 \mathrm{a}$ & $4.245 \mathrm{a}$ & $4.067 \mathrm{a}$ \\
1 Minggu Sekali & $4.120 \mathrm{a}$ & $3.676 \mathrm{a}$ & $3.654 \mathrm{a}$ & $3.817 \mathrm{a}$ \\
2 Minggu Sekali & $3.930 \mathrm{a}$ & $4.454 \mathrm{a}$ & $3.848 \mathrm{a}$ & $4.077 \mathrm{a}$ \\
\hline Rerata & $4.191 \mathrm{a}$ & $3.854 \mathrm{a}$ & $3.916 \mathrm{a}$ & $(-)$ \\
\hline Keterangan: & Angka pada baris dan kolom diikuti huruf sama tidak berbeda pada taraf nyata $(\alpha) 5 \%$ \\
& menurut uji DMRT. (-): Tidak terjadi interaksi antar faktor.
\end{tabular}

\subsection{Berat Segar Trubus}

Berdasarkan hasil sidik ragam (Anova) tidak terjadi interaksi antara perlakuan aplikasi PGPR dan jenis pestisida. Namun pemberian pestisida hayati meningkatkan berat segar trubus dibanding perlakuan pestisida ekstrak daun sirih dan kontrol, demikian juga aplikasi PGPR tidak memberikan pengaruh yang nyata namun pada perlakuan pengaplikasian 2 minggu sekali memberikan berat segar trubus tertinggi dibandingkan dengan perlakuan lainya.

Tabel 4. Berat Segar Trubus (g)

\begin{tabular}{lcccc}
\hline \multirow{2}{*}{ Aplikasi PGPR } & \multicolumn{3}{c}{ Jenis Pestisida } & \multirow{2}{*}{ Rerata } \\
\cline { 2 - 4 } & Kontrol & Daun Sirih & Hayati & \\
\hline Kontrol & $15,23 \mathrm{a}$ & $15,99 \mathrm{a}$ & $17,78 \mathrm{a}$ & $16,33 \mathrm{a}$ \\
1 Minggu Sekali & $15,39 \mathrm{a}$ & $17,99 \mathrm{a}$ & $18,44 \mathrm{a}$ & $17,27 \mathrm{a}$ \\
2 Minggu Sekali & $18,43 \mathrm{a}$ & $17,06 \mathrm{a}$ & $19,60 \mathrm{a}$ & $18,36 \mathrm{a}$ \\
\hline Rerata & $16,35 \mathrm{a}$ & $17,01 \mathrm{a}$ & $18,61 \mathrm{a}$ & $(-)$ \\
\hline Keterangan: & Angka pada baris dan kolom diikuti huruf sama tidak berbeda pada taraf nyata ( $\alpha) 5 \%$ \\
& menurut uji DMRT. (-): Tidak terjadi interaksi antar faktor.
\end{tabular}

\subsection{Berat Kering Trubus}

Hasil sidik ragam (Anova) menunjukkan tidak terjadi interaksi antara perlakuan aplikasi PGPR dan jenis pestisida. Jenis pestisida berpengaruh nyata terhadap berat kering trubus dimana pemberian pestisida hayati menghasilkan trubus kering paling berat dan berbeda nyata dengan trubus kering selada yang tidak diberikan pestisida. Aplikasi PGPR tidak memberikan pengaruh yang nyata namun pada perlakuan pengaplikasian 2 minggu sekali memberikan nilai tertinggi dibandingkan dengan perlakuan lainnya.

Tabel 5. Berat Kering Trubus (g)

\begin{tabular}{lcccc}
\hline \multirow{2}{*}{ Aplikasi PGPR } & \multicolumn{3}{c}{ Jenis Pestisida } & \multirow{2}{*}{ Rerata } \\
\cline { 2 - 4 } & Kontrol & Daun Sirih & Hayati & \\
\hline Kontrol & $4,07 \mathrm{a}$ & $3,65 \mathrm{a}$ & $4,33 \mathrm{a}$ & $4,01 \mathrm{a}$ \\
1 Minggu Sekali & $5,88 \mathrm{a}$ & $6,49 \mathrm{a}$ & $6,34 \mathrm{a}$ & $6,24 \mathrm{a}$ \\
2 Minggu Sekali & $6,72 \mathrm{a}$ & $6,80 \mathrm{a}$ & $6,63 \mathrm{a}$ & $6,72 \mathrm{a}$ \\
\hline Rerata & $5,56 \mathrm{~b}$ & $5,65 \mathrm{ab}$ & $5,77 \mathrm{a}$ & $(-)$ \\
\hline Keterangan: Angka pada baris dan kolom diikuti huruf sama tidak berbeda pada taraf nyata $(\alpha) 5 \%$
\end{tabular}
menurut uji DMRT. (-): Tidak terjadi interaksi antar faktor.

\subsection{Berat Segar Akar}

Hasil sidik ragam (Anova) menunjukkan bahwa perlakuan aplikasi PGPR dan jenis pestisida terhadap berat segar akar tidak terjadi interaksi. Namun pemberian pestisida hayati meningkatkan berat segar akar dibanding perlakuan pestisida ekstrak daun sirih dan kontrol, demikian juga aplikasi PGPR tidak memberikan pengaruh yang nyata namun pada perlakuan pengaplikasian 2 minggu sekali memberikan nilai tertinggi dibandingkan dengan perlakuan lainnya.

Tabel 6. Berat Segar Akar (g)

\begin{tabular}{lcccc}
\hline \multirow{2}{*}{ Aplikasi PGPR } & \multicolumn{3}{c}{ Jenis Pestisida } & \multirow{2}{*}{ Rerata } \\
\cline { 2 - 4 } & Kontrol & Daun Sirih & Hayati & \\
\hline Kontrol & $5,84 \mathrm{a}$ & $5,86 \mathrm{a}$ & $6,56 \mathrm{a}$ & $6,09 \mathrm{a}$ \\
1 Minggu Sekali & $6,66 \mathrm{a}$ & $6,33 \mathrm{a}$ & $6,42 \mathrm{a}$ & $6,47 \mathrm{a}$ \\
2 Minggu Sekali & $6,18 \mathrm{a}$ & $6,36 \mathrm{a}$ & $6,92 \mathrm{a}$ & $6,49 \mathrm{a}$ \\
\hline Rerata & $6,23 \mathrm{a}$ & $6,19 \mathrm{a}$ & $6,63 \mathrm{a}$ & $(-)$ \\
\hline Keterangan: & Angka pada baris dan kolom diikuti huruf sama tidak berbeda pada taraf nyata $(\alpha) 5 \%$ \\
& menurut uji DMRT. (-): Tidak terjadi interaksi antar faktor.
\end{tabular}

\subsection{Berat Kering Akar}

Hasil sidik ragam (Anova) menunjukkan tidak terjadi interaksi antar perlakuan aplikasi PGPR dan jenis pestisida. Namun pemberian pestisida hayati meningkatkan berat kering akar dibanding perlakuan pestisida ekstrak daun sirih dan kontrol. Aplikasi PGPR memberikan pengaruh yang nyata pada berat kering akar dimana pengaplikasian 2 minggu sekali menghasilkan akar kering yang paling berat dan berbeda nyata dengan kontrol.

\section{Tabel 7. Berat Kering Akar (g)}

\begin{tabular}{lcccc}
\hline \multirow{2}{*}{ Aplikasi PGPR } & \multicolumn{3}{c}{ Jenis Pestisida } & \multirow{2}{*}{ Rerata } \\
\cline { 2 - 4 } & Kontrol & Daun Sirih & Hayati & \\
\hline Kontrol & $2,06 \mathrm{~b}$ & $2,06 \mathrm{~b}$ & $2,09 \mathrm{~b}$ & $2,07 \mathrm{~b}$ \\
1 Minggu Sekali & $2,21 \mathrm{~b}$ & $2,10 \mathrm{~b}$ & $2,19 \mathrm{~b}$ & $2,17 \mathrm{ab}$ \\
2 Minggu Sekali & $2,38 \mathrm{ab}$ & $2,06 \mathrm{~b}$ & $2,96 \mathrm{a}$ & $2,47 \mathrm{a}$ \\
\hline Rerata & $2,22 \mathrm{a}$ & $2,07 \mathrm{a}$ & $2,42 \mathrm{a}$ & $(-)$ \\
\hline Keterangan: & Angka pada baris dan kolom diikuti huruf sama tidak berbeda pada taraf nyata $(\alpha) 5 \%$ \\
& menurut uji DMRT. (-): Tidak terjadi interaksi antar faktor.
\end{tabular}

\subsection{Berat Segar Tanaman}

Hasil sidik ragam (Anova) menunjukkan tidak terjadi interaksi antara perlakuan aplikasi PGPR dan jenis pestisida terhadap berat segar tanaman selada. Namun pemberian pestisida hayati meningkatkan berat segar tanaman dibanding perlakuan pestisida ekstrak daun sirih dan kontrol, demikian juga aplikasi PGPR tidak memberikan pengaruh yang nyata namun pada perlakuan pengaplikasian 2 minggu sekali memberikan nilai tertinggi dibandingkan dengan perlakuan lainnya.

\section{Tabel 8. Berat Segar Tanaman (g)}

\begin{tabular}{lcccc}
\hline \multirow{2}{*}{ Aplikasi PGPR } & \multicolumn{3}{c}{ Jenis Pestisida } & \multirow{2}{*}{ Rerata } \\
\cline { 2 - 4 } & Kontrol & Daun Sirih & Hayati & \\
\hline Kontrol & $21,07 \mathrm{a}$ & $21,85 \mathrm{a}$ & $24,34 \mathrm{a}$ & $22,42 \mathrm{a}$ \\
1 Minggu Sekali & $22,04 \mathrm{a}$ & $24,32 \mathrm{a}$ & $24,86 \mathrm{a}$ & $23,74 \mathrm{a}$ \\
2 Minggu Sekali & $24,61 \mathrm{a}$ & $23,42 \mathrm{a}$ & $26,52 \mathrm{a}$ & $24,85 \mathrm{a}$ \\
\hline Rerata & $22,57 \mathrm{a}$ & $23,20 \mathrm{a}$ & $25,24 \mathrm{a}$ & $(-)$ \\
\hline Keterangan: & Angka pada baris dan kolom diikuti huruf sama tidak berbeda pada taraf nyata $(\alpha) 5 \%$ \\
& menurut uji DMRT. (-): Tidak terjadi interaksi antar faktor.
\end{tabular}

\subsection{Berat Kering Tanaman}

Hasil sidik ragam (Anova) menunjukkan tidak terjadi interaksi antara perlakuan aplikasi PGPR dan jenis pestisida terhadap berat kering tanaman selada. Namun pemberian pestisida hayati meningkatkan berat kering tanaman dibanding perlakuan pestisida ekstrak daun sirih dan kontrol, demikian juga aplikasi PGPR tidak memberikan pengaruh yang nyata namun pada perlakuan pengaplikasian 2 minggu sekali memberikan nilai tertinggi dibandingkan dengan perlakuan lainnya.

\section{Tabel 9. Berat Kering Tanaman (g)}

\begin{tabular}{lcccc}
\hline \multirow{2}{*}{ Aplikasi PGPR } & \multicolumn{3}{c}{ Jenis Pestisida } & \multirow{2}{*}{ Rerata } \\
\cline { 2 - 4 } & Kontrol & Daun Sirih & Hayati & \\
\hline Kontrol & $6,13 \mathrm{a}$ & $5,71 \mathrm{a}$ & $6,42 \mathrm{a}$ & $6,09 \mathrm{a}$ \\
1 Minggu Sekali & $8,09 \mathrm{a}$ & $8,59 \mathrm{a}$ & $8,53 \mathrm{a}$ & $8,41 \mathrm{a}$ \\
2 Minggu Sekali & $9,10 \mathrm{a}$ & $8,86 \mathrm{a}$ & $9,59 \mathrm{a}$ & $9,18 \mathrm{a}$ \\
\hline Rerata & $7,77 \mathrm{a}$ & $7,72 \mathrm{a}$ & $8,18 \mathrm{a}$ & $(-)$ \\
\hline Keterangan: & Angka pada baris dan kolom diikuti huruf sama tidak berbeda pada taraf nyata $(\alpha) 5 \%$ \\
& menurut uji DMRT. (-): Tidak terjadi interaksi antar faktor.
\end{tabular}

\subsection{Berat Segar Tanaman Per Petak}

Dari hasil sidik ragam (Anova) tidak terjadi interaksi antara perlakuan aplikasi PGPR dan jenis pestisida terhadap berat segar tanaman per petak

$\underline{\text { Tabel 10. Berat Segar Tanaman Per Petak (g) }}$

\begin{tabular}{lcccc}
\hline \multirow{2}{*}{ Aplikasi PGPR } & \multicolumn{3}{c}{ Jenis Pestisida } & \multirow{2}{*}{ Rerata } \\
\cline { 2 - 4 } & Kontrol & $\begin{array}{c}\text { Daun } \\
\text { Sirih }\end{array}$ & Hayati & \\
\hline Kontrol & $119,51 \mathrm{a}$ & $119,65 \mathrm{a}$ & $131,69 \mathrm{a}$ & $123,61 \mathrm{a}$ \\
1 Minggu Sekali & $136,17 \mathrm{a}$ & $158,76 \mathrm{a}$ & $210,40 \mathrm{a}$ & $168,44 \mathrm{a}$ \\
2 Minggu Sekali & $211,80 \mathrm{a}$ & $296,27 \mathrm{a}$ & $253,06 \mathrm{a}$ & $253,71 \mathrm{a}$ \\
\hline Rerata & $155,82 \mathrm{a}$ & $191,56 \mathrm{a}$ & $198,38 \mathrm{a}$ & $(-)$ \\
\hline Keterangan: & Angka pada baris dan kolom diikuti huruf sama tidak berbeda pada taraf nyata $(\alpha) 5 \%$
\end{tabular}


Selada yang diberi jenis pestisida hayati memiliki berat segar tanaman per petak paling tinggi dibanding pestisida daun sirih dan kontrol. Pemberian aplikasi PGPR juga tidak berpengaruh nyata tetapi perlakuan 2 minggu sekali memberikan tanaman segar per petak yang lebih berat dibanding pemberian 1 minggu sekali dan kontrol.

\subsection{Berat Kering Tanaman Per Petak}

Hasil sidik ragam (Anova) menunjukkan tidak terjadi interaksi antara perlakuan aplikasi PGPR dan jenis pestisida. Namun pemberian pestisida hayati meningkatkan berat kering tanaman per petak dibanding perlakuan pestisida ekstrak daun sirih dan kontrol, demikian juga aplikasi PGPR tidak memberikan pengaruh yang nyata namun pada perlakuan pengaplikasian 2 minggu sekali memberikan nilai tertinggi dibandingkan dengan perlakuan lainnya

$\underline{\text { Tabel 11. Berat Kering Tanaman Per Petak (g) }}$

\begin{tabular}{lcccc}
\hline \multirow{2}{*}{ Aplikasi PGPR } & \multicolumn{3}{c}{ Jenis Pestisida } & \multirow{2}{*}{ Rerata } \\
\cline { 2 - 4 } & Kontrol & Daun Sirih & Hayati & \\
\hline Kontrol & $20,38 \mathrm{a}$ & $19,81 \mathrm{a}$ & $21,84 \mathrm{a}$ & $20,68 \mathrm{a}$ \\
1 Minggu Sekali & $20,65 \mathrm{a}$ & $21,46 \mathrm{a}$ & $21,98 \mathrm{a}$ & $21,36 \mathrm{a}$ \\
2 Minggu Sekali & $21,64 \mathrm{a}$ & $22,95 \mathrm{a}$ & $22,12 \mathrm{a}$ & $22,24 \mathrm{a}$ \\
\hline Rerata & $20,89 \mathrm{a}$ & $21,40 \mathrm{a}$ & $21,98 \mathrm{a}$ & $(-)$ \\
\hline Keterangan: & Angka pada baris dan kolom diikuti huruf sama tidak berbeda pada taraf nyata $(\alpha) 5 \%$ \\
& menurut uji DMRT. (-): Tidak terjadi interaksi antar faktor.
\end{tabular}

\subsection{Indeks Panen}

Hasil sidik ragam (Anova) menunjukkan tidak terjadi interaksi antara perlakuan aplikasi PGPR dan jenis pestisida. Namun pemberian pestisida hayati meningkatkan indeks panen dibanding perlakuan pestisida ekstrak daun sirih dan kontrol, demikian juga aplikasi PGPR tidak memberikan pengaruh yang nyata namun pada perlakuan pengaplikasian 1 minggu sekali memberikan nilai tertinggi dibandingkan dengan perlakuan lainnya.

Tabel 12. Indeks Panen (\%)

\begin{tabular}{lcccc}
\hline \multirow{2}{*}{ Aplikasi PGPR } & \multicolumn{3}{c}{ Jenis Pestisida } & \multirow{2}{*}{ Rerata } \\
\cline { 2 - 4 } & Kontrol & Daun Sirih & Hayati & \\
\hline Kontrol & $95,19 \mathrm{a}$ & $95,15 \mathrm{a}$ & $95,14 \mathrm{a}$ & $95,16 \mathrm{a}$ \\
1 Minggu Sekali & $94,76 \mathrm{a}$ & $95,91 \mathrm{a}$ & $96,77 \mathrm{a}$ & $95,81 \mathrm{a}$ \\
2 Minggu Sekali & $95,47 \mathrm{a}$ & $97,54 \mathrm{a}$ & $97,11 \mathrm{a}$ & $96,71 \mathrm{a}$ \\
\hline Rerata & $95,14 \mathrm{a}$ & $96,20 \mathrm{a}$ & $96,34 \mathrm{a}$ & $(-)$ \\
\hline Keterangan: & Angka pada baris dan kolom diikuti huruf sama tidak berbeda pada taraf nyata $(\alpha) 5 \%$ \\
& menurut uji DMRT. (-): Tidak terjadi interaksi antar faktor.
\end{tabular}

\subsection{Pembahasan}

Berdasarkan semua parameter pertumbuhan yang diamati, selada darat yang diberi pestisida hayati pertumbuhannya jauh lebih baik dibandingkan dengan selada darat yang diberi pestisida ekstrak daun sirih dan kontrol. Hasil penelitian menunjukkan bahwa selada darat yang diberi pestisida hayati mengurangi hama dan penyakit terhadap pertumbuhan tanaman selada darat yang dapat diekspresikan dalam bentuk tinggi tanaman $(8,36 \mathrm{~cm})$, jumlah daun paling banyak $(5,81)$ dengan permukaan daun paling luas $\left(3916 \mathrm{~cm}^{2}\right)$, trubus segar paling berat $(18,61 \mathrm{~g})$, berat kering trubus $(5,77 \mathrm{~g})$, berat segar akar $(6,63 \mathrm{~g})$, berat kering akar $(2,42 \mathrm{~g})$, berat segar tanaman $(25,24 \mathrm{~g})$, berat kering tanaman $(8,18 \mathrm{~g})$, berat segar tanaman per petak $(198,38 \mathrm{~g})$, berat kering tanaman per petak $(21,98 \mathrm{~g})$ dan indeks panen $(96,34 \%)$.

Aplikasi PGPR dengan frekuensi penyiraman 2 minggu sekali memberikan hasil terbaik terhadap pertumbuhan tanaman selada yang diekspresikan dalam bentuk tinggi tanaman $(8,06 \mathrm{~cm})$, permukaan daun terluas $\left(4077 \mathrm{~cm}^{2}\right)$, berat segar trubus $(18,36 \mathrm{~g})$, berat kering trubus $(6,72 \mathrm{~g})$, berat segar akar $(6,49 \mathrm{~g})$, berat kering akar $(2,47 \mathrm{~g})$, berat segar tanaman $(24,85 \mathrm{~g})$, berat kering tanaman $(9,18$ $\mathrm{g})$, berat segar tanaman per petak $(253,71 \mathrm{~g})$, berat kering tanaman per petak $(22,24 \mathrm{~g})$ dan indeks panen $(96,71 \%)$. Diduga hal ini terjadi karena aplikasi PGPR meningkatkan resistensi tanaman. Hasil penelitian Sentilraja et al. (2012) menyatakan bahwa campuran bioformulasi PGPR yang mengandung $P$. fluorescens dengan fungi entomopatogen. Beauveria bassiana secara signifikan dapat menekan hama leafminer Aproaerema modicella dan penyakit busuk yang disebabkan oleh Sclerotium rolfsii pada kacang tanah. Susanto (2008) menyatakan PGPR sebagai pengendalian hayati yang dapat menekan populasi hama dengan menginduksi resistensi pada tanaman.

Menurut (Gusti et al., 2012) PGPR merupakan konsorsium bakteri yang aktif mengkolonisasi akar tanaman yang berperan penting dalam meningkatkan pertumbuhan tanaman, hasil panen dan kesuburan lahan. Hal ini dapat terlihat dimana aplikasi PGPR secara nyata berpengaruh terhadap berat kering akar selada.

\section{Simpulan}

Tidak ada pengaruh interaksi antara aplikasi PGPR dan jenis pestisida terhadap pertumbuhan dan hasil selada. Aplikasi PGPR hanya berpengaruh nyata terhadap berat kering akar sedangkan jenis pestisida hanya berpengaruh terhadap berat kering trubus. Aplikasi PGPR dengan frekuensi dua minggu sekali menghasilkan selada setiap petak paling berat (253,71 g), sedangkan jenis pestisida yang menghasilkan selada setiap petak paling berat adalah pestisida hayati $(198,38 \mathrm{~g})$.
Pustaka

Departemen Pertanian. 2009. Peraturan Menteri Pertanian Republik Indonesia Nomor No 28/ Permentan/SR.130/5/2009 tentang Pupuk Organik, Pupuk Hayati dan Pembenah Tanah.

Figuiredo. M., Seldin. L. Araujo. F. \& Mariano. R. (2010). Plant Growth Promoting Rhizobacteria : Fundamentals and Applications. Microbiology Monographs (18)

Gomez, K. A. and Gomez, A. A. 1995. Prosedur Statistik Untuk Penelitian Pertanian. Edisi ke 2. UI Press: Jakarta.

Gusti, I.N., Khalimi, K.,. Dewa, I.N. Ketut., \& Dani, S. (2012). Aplikasi Rhizobacteri Pantoea agglomerans untuk Meningkatkan Pertumbuhan Dan Hasil Tanaman Jagung. (Zea mays.L) Varietas hibrida BISI-2.Agrotrop. 2 (1):1-9.

Rukmana. 1994. Bertanam Selada da Andewi. Kanisius, Yogyakarta

Senthilraja G, Anand T, Kennedy JS, Raguchander T, Samiyappan R. 2012. Plant growth promoting rhizobacteria (PGPR) and entomopathogenic fungus bioformulation enhance the expression of defense enzymes and pathogenesis-related protein in groundnut plant against leafminer insect and collar rot pathogen. Physiological and Molecular Plant Pathology. 82:1019

Simanungkalit, R. D. M. 2001. Aplikasi pupuk hayati dan pupuk kimia; suatu pendekatan terpadu. Bul Agrobiol 4: 56-61.

Soesanto L. 2008. Pengantar Pengendalian Hayati Penyakit Tanaman. Jakarta (ID): PT Rajagrafindo Persada.

Vessey, J. K. 2003. Plant growth promoting rhizobacteria as biofertilizer. Plant Soil 255: 571 - 586.

Wicaksono, A. 2008. Penyimpanan Bahan Makanan Serta Kerusakan Selada. Skripsi . Fakultas Politeknik Kesehatan. Yogyakarta 